\title{
The Metaphysical School of Poetry of the Seventeenth Century
}

\author{
Prof. Dr. Mohammed Farooq Salih Albadri \\ Department of Doctrine, College of Islamic Sciences , The Iraqia University \\ DOI: 10.29322/IJSRP.11.05.2021.p11336 \\ http://dx.doi.org/10.29322/IJSRP.11.05.2021.p11336
}

\begin{abstract}
There is common preservation that the term "metaphysical" is utilized to portray a gathering of seventeenth-century English artists, who wrote in a specific way affected by, or in response to, works by John Donne. The chose not many related as such are known as the metaphysical artists, and their works marked as "metaphysical poetry". Precisely what the term metaphysical refers to, or what does it define this aspect requires some explanation. As indicated by the Cambridge Dictionary, metaphysical poetry identifies with the piece of theory that is tied in with getting presence and information"; while theory then again, is "the affective reason in viewing things with the aspect of the present reality and presence. Subsequently, by suggestion, however, till this day there is no fully effective definition of metaphysical poetry, as it requires a variety of characteristics which will be presented in this paper along with the brief history behind the metaphysical poets and inspirations.
\end{abstract}

Index terms : Metaphysical poetry, Literature, Seventheth Century, John Donne, Samuel Johnson .

\section{Introduction}

The word metaphysics itself is combined of two words, "meta" which is interpreted as "after" and "physics" which resembles matter, therefore the combined word is interpreted as after matter or behind physics, metaphysical poetry discusses subjects further behind the physical state, and focuses on the philosophical aspect, for example, spiritual and religious topics, such as the journey of life and whom to turn to and how to turn, associated with significant anxiety of the future, or discussing consciousness and the human awareness, along with the purpose of life in the form of rhymed and well-toned poetry.

Metaphysics is a complex phenomenon and there is not yet a descriptive definition for it, but it does distinguish itself by acquiring several characteristics, for example using strange and significant imaginary which emphasizes one of the main purposes of the metaphysical poem, that is to make the audience consider and think of thoughts they never considered or imagined, exaggeration, inserting comedy lines, paradoxes, and puns, use of metaphysical conceits which are complexes of making stretched comparisons between a physical matter and a spiritual aspect in a way to catch the audiences' attention and link their physical knowledge to the poet's spiritual purpose, and this feature was rarely used after the $17^{\text {th }}$ century, metaphysical poetry is also known for being highly intellectualized and uses rigid expressions.

The definition of metaphysical poetry has always been a concern of literature researches however these specific characteristics are what distinguish metaphysical poetry intellectuality and expressing individual concerns, imageries and conceits, expression of ideas and feelings openly, and development of logical arguments that presents new extraordinary thoughts and different points of view, all these aspects combined together to serve as the foundation of metaphysical poetry. Metaphysical poetry often discusses religious topics and concerns, which represent a significant aspect of spiritual poetry.

The poets of metaphysical poetry were a known group, who used the mentioned features and characteristics, they were educated men, and to show their education was their entire endeavor. as they neither duplicated nature nor life, neither copied matter nor presented aspects of intellect. Their considerations are frequently new and rare in value. The most heterogeneous thoughts are burdened together by viciousness; nature and workmanship are stripped for representations, examinations, and inferences; their learning teaches, and their nuance shocks'. These surprising correlations between things more dissimilar to than like are called conceits. Another characteristic of metaphysical poetry is significantly focused on and is argued. The names and history of the group will be mentioned in further discussion.

\section{Background}

The phrase "Metaphysical poets" was first labeled by the critic Samuel Johnson as he used it to refer to a loose group of English poets in the $17^{\text {th }}$ century. Samuel Johnson is a significant English poet and writer who created great change in the history of English literature he was born on the $18^{\text {th }}$ of September 1709, and passed away on the $13^{\text {th }}$ of December 1784 at 75 years old, he was born in 
Litchfield, Staffordshire and attended Pembroke College in Oxford, he later worked in many literature related jobs including editing and playwriting, he also worked as a critic, some of his most known remarkable works are "A Journey to the Western Islands of Scotland", and "A Dictionary of the English Language". The Oxford Dictionary of National Biography titled him as the man with most distinguished letters (Rogers, 2004).

The origins of the name "Metaphysical poet" is derived from a chapter of "Lives of The Most Eminent English Poets" in which Samuel Jackson mentions the appearance of a race of writers that could be termed as the metaphysical poets, as he was referring to the beginning of the $17^{\text {th }}$ century in 1744. Drummond of Hawthornden was also documented as an early author mentioning the term metaphysical as he wrote it in an undated letter from the $1630 \mathrm{~s}$.

The approach of metaphysical poetry was fresh and original and made significant changes in English literature, members of the loose group mentioned were:

\subsection{John Donne:}

Donne is considered to be the permanent poet of metaphysical poetry, born in 1572 to Roman Catholic parents and that religion was illegal back then, he grew up to become a poet and Anglican clerk, Donne was quite known and admired by his surrounding audience at that time, his poems were known to be sweet, emotional, and well-toned. He often wrote about religion, faith, divine love, and humans, he also inserts conceits, and extended metaphors, his work usually indicated powerful ambiguity by standing for many interpretations.

His reputation was well during his early days and he accessed significant fame later in his life as he was famous as a preacher, three decades after his death in 1631 there was successful publishes of his verses that caught poets' eyes. However, during restoration, his work was neglected and considered to be out of fashion. Through both the $18^{\text {th }}$ and $17^{\text {th }}$ century his work regained appreciation and publicity, overall his work was not significantly noticed till 1919 when his work was rediscovered by modern readers, and received the great appeal, as they considered his work to be a significant fusion between passion and intellect (Dagnall, 2020).

He was most known for the following poems

"Air and Angles", "An Anatomy of the World", and "The Anniversary" which were published in his poetry collection.

\subsection{George Herbert:}

Herbert is a British English poet, born on April the $3^{\text {rd }} 1593$, in Montgomery Castle, Wales. He is a younger brother of Edward Herbert. He was educated at home and eventually attended the Trinity College, Cambridge and was elected orator of the university in 1620 which he thought of as the finest place in a university, that position enabled him to acquire more significant positions in the near future as he was much involved in the court. Up till then his only acknowledged verses were written for special occasions in Latin and Greek, by 1625 Herbert turned to church as he was a man of religion as most metaphysical poets, he was ordained a priest in 1630 and became rector at Bemerton, he then meets and befriended a religious community of rural parishes, during his life Herbert wrote many poems and in his last time, he sends a manuscript to a friend, who was the creator of the religious group, asking him whether to post them or not, the friend Nicholas Ferrar chose to publish them and titled them The Temple: Sacred Poems and Private Ejaculations, in 1633 the same year which George Herbert passed away in.

His work often discussed personal beliefs and spiritual struggles including belief in God, and personal beliefs (Augustyn \& Zelazko, 2020).

\subsection{Henry Vaughan:}

Born on April 17 th 1622 , in Llansantffraed, Breconshire, Wales. He received education in London as he studied law; he was called home when the first Civil War occurred and never preceded his career. He published his poems in 1646 with the Tenth Satyre of Juvenal Englished, and produced a second volume in the following year, he later got converted as an influence of reading the works of the religious poet George Herbert, the prose Mount of Olives: or, Solitary Devotions, which represented his religious view and proved the depth of his beliefs, he then continued to publish volume sequences, as well as translating a verity of work including short morals, religious paper , and even medical paper, as he started to practice medicine officially in the $1650 \mathrm{~s}$, he was a quite gifted poet and acquired a significantly spiritual vision, he also demonstrated great poems about nature and other subjects, he was highly inspirited by George Herbert, but he was also one of the most original poets of his time, like the rest of the group his poetry didn't receive much credit during his lifetime and only got appreciated after the $17^{\text {th }}$ century, his most popular work was religious and spiritual (Augustyn \& Zeidan, 2020).

\subsection{Thomas Traherne:}

He was born in 1637, in Hereford, England. Thomas Trahern was a son of a shoemaker, received his education at Oxford University, in 1660 he was ordained as an Anglican clergyman, he then served in a parish close to Credenhill, and later on became the chaplain to Lord Keeper of the Great Seal, Sir Orlando Bridgeman. During his entire lifetime, he only managed to publish one work, titled "Roman Forgeries" in 1673; he only had little works involved with his name. His most popular work was Christian Ethics which was published in 1675 posthumously. His other work "Thanksgivings" was published in 1699 anonymously, and so was the majority of his work, until 1896 when two of his writings were rediscovered by chance in a bookstall in London, other works of his were republished in the 1900s. He was often considered as the last one of the metaphysical poets and was popular for his visionary innocence of childhood (Jayakar, 2020).

\subsection{Andrew Marvell:}

In the early years twentieth century Andrew's work was finally recognized, and due to the scarcity of his personal This publication is licensed under Creative Commons Attribution CC BY. 
information along with inconsistencies within his work Andrew was an interesting character for researchers and readers. Born and raised in Yorkshire, England, on March 31, 1621, of a religious family, Marvell's father was a lecturer at Holy Trinity Church. At twelve years old Andrew started college at Trinity College, Cambridge, and two years later two of his poems were published one in Latin and the second in Greek. After college, he stayed to complete his master degree, till 1641 when his father drowned and Andrew abandoned his studies, later in his life he was elected as a member of Parliament for Hull, which he held till his death (Kemp, 2006).

\subsection{Richard Crashaw:}

Richard Crashaw was the child of a Puritan priest ( 1612-1649) yet he didn't stay inside the Anglican overlap and turned into a Catholic when he was around 22 years of age. He took his life in Rome as secretary to Cardinal Palotta. While still at the college, he was a specialist Latin artist. The primary assortment of his sonnets which was distributed after his demise was Delights of the Muses. There is in this assortment an imitative sonnet on the melody of a songbird, Music's Duel. His most punctual sonnet Wishes to his Supposed Mistress is musically remarkable and lists the blessings which he might want his cherished to have. In 1646 he distributed Steps to the Temple which was an assortment of sonnets composed before his change. In this assortment Sospetto d' Herode and The Weeper motivate esteem. While yet an Anglican, Crashaw imagined impassioned love for Saint Teresa, and he got back to her as a Catholic to compose his most glorious psalm, The Flaming Heart, The trip of sacred love which closes this sonnet is maybe the most passionate result of English strict verse. Crashaw's sonnets, every one of them, have a few issues. At times ludicrous, he dissipated vanities all over the place.

While he was less educated than Herbert, and keeping in mind that his language was less basic and exact, he was warmer, shading, and congruity (Dutta, 2013).

\section{Discuss Session}

The seventeenth-century metaphysical poetry is thought to be the closer and most related poetry phase to our generation's feelings and mentality and poetry compared to the poetry and expressions of the eighteenth and nineteenth centuries, however many voices refused the declaration of our generation as a metaphysical age, while others consider the likeness as a considerable fact that forces us to study and learn more about the seventeenth century and its metaphysical age (Eliot, 2014). One of the main issues is the inability to define metaphysical poetry precisely, since it still hasn't been successfully defined it makes it hard to determine the position of our generation compared to that specific age, mister Eliot the author of "The Varieties of Metaphysical Poetry" presented and supported the opinion that one of the main reasons of the inability to define metaphysical poetry is derived from the fact that the word "metaphysical" itself which was first used by Dryden and adopted by Johnson, was not used by metaphysicians or individuals with a metaphysical concern or a part of a metaphysical cast whatsoever. Therefore their terminology may not be as accurate as it should. Also, the philosophical aspect of metaphysics was not practiced in wide ranges, it was narrow and rarely discussed, and therefore both Dryden and Johnson did not employ the term with sufficiency knowledge. What Eliot desires researchers to consider is the variety and differences between the poets and poems of the seventeenth century, as he believes that the term was stretched to cover all the poets and that caused the ineffective definitions (Eliot, 2014).

An attempt of expressing the term metaphysical was "gives the feeling that metaphysical poetry talks about the idea of the universe", she proceeds with that "Donne and the artists most affected by him was not estimating the idea of things, therefore it was termed beyond physical. when Donne composes, he is communicating a perspective by alluding to a foundation of thoughts". Chiefly, this implies that as opposed to depicting the idea of things essentially in his sonnets, Donne really uses it (for example the idea of things) as a source of perspective to pass on his contemplations. In this sense, Donne and his devotees were not actually on top of the importance of the term metaphysical as referenced before. In this manner, the term is apparently thought of (by a few) as being fairly indiscreetly connected to the specific gathering of writers and their verses. As Eliot (2014) puts it, the expression has since quite a while ago carried out responsibility as a term of misuse, or as the name of a curious and wonderful taste. however, by contending on the precision of the term, pundits were not at all attempting to deny the Metaphysics. They were simply bringing up certain contentions with respect to the term, which most researchers regularly underestimated (Azam, 2020).

Similarities between different metaphysical poetry and other types of poetry are clearly present, for example when comparing religious metaphysical poetry to contemporary secular love poetry, many similarities are present regard to turning especially on the aspect that the individual speaker's focus on the object of his love, to whom he turns and whose turn the speaker's desire. While English poetry up to Donne and Herbert presents strong influence Petrarchan love poetry, in which the individual feelings are presented in a traditional poetic method, as well as the absence of a beloved one, which was followed through the development of English poetry, an example from Wyatt to Shakespeare, by foregrounding a principle individual and his concerns as this type of personal stance has emerged in varieties of religious poetry in the seventeenth and sixteenth centuries. The poem's individual expression makes it a possible stage of self-analysis and soul-searching thus expressing the spiritual mindset (Dörge., 2018). Generally, the notion of the poet exploring his journey and having concerns of what direction to take and how to take it and trying to comprehend the journey in a better way with further depth a joined concept since poetry covers the most intimate and condense spaces.

Considering such connections it's important to analyze what makes poets such as Donne or Herbert and their successors "metaphysical" since the criticism was so focused on the sophistication and depth of the style and the poet's imagination and capabilities, but never criticized why that is here. In the mainframe of literal connection, this only makes the definition harder and 
opens up a variety of meanings. When examining the considered "metaphysical poetry" it becomes clear that most of it are religious poetry therefore metaphysical poets were situated in a context characterized, by the prominence of religion and religious discourses.

And therefore as proof of this fact most typical or important metaphysical poets were writers of religious poetry (Dörge., 2018). Some go further to estimate the concern of salvation as the main incentive of most metaphysical poetry, as the personal anxiety of the speakers for self-salvation is what drove them to turn to God and it is a general, recurrent feature in religious metaphysical poetry to display anxiety of the future of the human's soul, although in the sixteenth and seventeenth-century fundamental doubt turned to a serious option, as the concern of validation has become considered to pressuring and overwhelming, as this concern was the leading cause of turning to God and creating a religious relationship, to insure and create hope for the salvation and security.

Another point of consideration is the expectation of reciprocity that exceeds regular hope, in sacred poetry, the speaker assumes God's response with salvation, and in love poetry mainly "The Canonization" since the lovers' feeling is reciprocated. While other texts represented unfulfilled expectations of reciprocity, for example, love poetry in which love is not required, for example, is "Pamphilia to Amphilanthus", in which the speaker doesn't know where to turn since he seeks the lover's direction, but feels trapped in a labyrinth of love and therefore confusion (Larson, 2019). Yet in this condition also the speaker only writes for hopes of reciprocity.

The anxiety of the soul isn't only present in metaphysical poetry but is also present in the poets' use of language and the syntax and vocabulary of each poem, as well as the use of imagination and conceit, after comparison it becomes clear that the union of feelings and thoughts in the metaphysical poetry is derived from faithful expressions of the content of the poem, presented within the poem language (Dörge., 2018).

Another special aspect is the peculiar use of language which is a significant factor that specifies metaphysical poetry, most significant is Donne and Herbert's use of religious language for example Donne Asals 1979, in which he significantly points out his continued emphasis on dissecting biblical languages usage and grammar application as the appropriate way to approach God, and points out this emphasis as an explanation and support to his use of language in the Holy sonnets. Some argue that Donne's language use presents a seeker attempting to verbally get closer to God, while others argue that based on his sacred poetry within others that Donne's poetry acts rhetorically, using whatever strategy helps achieve his goals.

While Herbert's use of language is considered to be a sacred parody, as he argues that religious poetry differs from secular, but still uses the same method to approach God, and therefore is considered or labeled as a sacred parody, some argue the Herbert in "The Temple" and in many instances offers an ambiguous reading deliberately.

As we can see the analyzed aspect of metaphysical poetry doesn't fully consider all the desired aspects, and most concerns and notes only include one poem of the speaker's work, while others focus on particular characteristics completely neglecting other significant characteristics only. And there is rarely any analysis of the general aspect of turning although it presented great value to the metaphysical poetry.

\section{V.Recommendations}

Different approaches of analyzing the metaphysical poetry of the seventeenth century, for example, an attempt of analyzing each complex poem individually and in relative, considering the fact that high complex poems can only be analyzed in their entirety to be able to fully comprehend the speaker's meanings and choice of words and syntax although each chapter represents a different aspect of tuning.

Also analyzing all aspects of the poem and not just focusing on a couple of specific aspects, while also focusing on the works of John Donne and George Herbert, since they are the main poets in the metaphysical poetry cast, as they presented the first and second generation of metaphysical poetry in the seventeenth century and the rest of the poets have learned under them and practices through their presentation.

Comparisons between Donne and Herbert's poems would be a significant job since their poetry is similar in aspects and different in others, for example, both their religious poems are similar in their individual concerns and topics, along with language usage and imagery, but present differences in toning and styling,

\section{V.Conclusion}

In conclusion the age of metaphysical poetry successfully presented great educational benefits and presented significant value to the English literature, the significance of this age is quite clear as it presented new aspects of value and new methods of expression that was not known before the seventeenth century, the language and conceits used in metaphysical poetry are unique and present significant cleverness, it also focuses on driving the audience to imagine what they have not thought of before, and capture their imaginations, metaphysical poetry was such a shift in English poetry that individuals study and analyze to this day, most metaphysical poets suffered from different struggles, but the one they almost all had in common was self anxiety, presented in the fear of the future of the human soul, which is what lead them to speak and express their thoughts on the journey of life and turning points, also most seventeenth century metaphysical poets were born and raised into religious families and therefore carried out a religious mind set, and some of them even held religious positions during his life time, which explains the majority of religious poetry over other types of poetry, other topics such as love was also present, and it shared the common point of desiring reciprocity results whether from God or the loved one.

Many other characteristics can identify metaphysical poetry, including specific use of language, toned, and syntax.

This publication is licensed under Creative Commons Attribution CC BY. 
According to researches our generation is more related to the seventeenth-century poets rather than the eighteenth and nineteenthcentury poets.

However many constraints prevented the labeling of this decade as one, and since there is no specific definition of that cretin age, therefore it's highly significant to analyze and consider the works of the first two generations of this age John Donne, and George Herbert.

\section{References}

[1] Augustyn, A., \& Zeidan, A. (2020). Henry Vaughan | English poet. Encyclopedia Britannica. Retrieved 10 November 2020, from https://www.britannica.com/biography/Henry-Vaughan.

[2] Augustyn, A., \& Zelazko, A. (2020). George Herbert | British poet. Encyclopedia Britannica. Retrieved 5 November 2020, from https://www.britannica.com/biography/George-Herbert.

[3] Azam, Y. (2020). An Analysis Of Selected Characteristics In Metaphysical Poetry. European Proceedings Of Social And Behavioural Sciences Epsbs. https://doi.org/10.15405/epsbs.2020.10.02.69

[4] Dagnall, I. (2020). John Donne | Poetry Foundation. Poetry Foundation. Retrieved 5 November 2020, from https://www.poetryfoundation.org/poets/john-donne.

[5] Dörge., C. (2018). The Notion of Turning in Metaphysical Poetry. Lit Verlag Wien.

[6] Dutta, Sibaprasad. (2013). Metaphysical Poetry: A Bird's Eye View. Literary World.

[7] Eliot, T. (2014). The varieties of metaphysical poetry. Houghton Mifflin Harcourt.

[8] Jayakar, T. (2020). About Thomas Traherne | Academy of American Poets. Poets.org. Retrieved 10 November 2020, from https://poets.org/poet/thomas-traherne.

[9] Kemp, L. (2006). An Andrew Marvell Chronology. Basingstoke And New York, NY: Palgrave Macmillan, 20(3), 31-32. https://doi.org/10.1108/09504120610655448.

[10] Larson, K. (2019). Pamphilia to Amphilanthus in Manuscript and Print by Lady Mary Wroth. Early Modern Women, 13(2), 128-131. https://doi.org/10.1353/emw.2019.0019.

[11] Rogers, P. (2004). Johnson, Samuel (1709-1784), author and lexicographer. Oxford Dictionary Of National Biography. https://doi.org/10.1093/ref:odnb/14918. AUTHORS

First Author - Mohammed Farooq Salih Albadri, Prof. Dr. Comparative Jurisprudence, College of Islamic Sciences, The Iraqia University, Baghdad, Iraq, dr_mohd61@yahoo.com.

Correspondence Author - - Mohammed Farooq Salih Albadri, dr mohd61@yahoo.com., albadrimohammed07@gmail.com Mobile; 009647700876966. 